\author{
Сања Зоран Арежина
}

\title{
Улога КПК у развоју кинеског модела инвестирања и давања помоћи иностранству
}

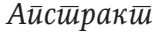

Народна Република Кина је већ педесетих година 20. века почела да спроводи политику давања инвестиција и помоћи иностранству. Иако су мотиви за то били различити у деценијама које су уследиле, кинеско руководство никада није одустало од одлуке да давање инвестиција и помоћи иностранству буде централни део кинеске спољне политике. Да би доказала хипотезу да је основни разлог развоја кинеског модела давања инвестиција и помоћи иностранству намера кинеског руководства да покаже да Народна Република Кина представља „одговорну велику силу” која доприноси решавању важних глобалних проблема, док у исто време ради на остваривању најважнијег циља - достизања „кинеског сна” до 2049. године, ауторка користи структурално-функционалну анализу и компаративну анализу.
\end{abstract}

Клучне речи:

Кина, инвестиције, помоћ, одговорна велика сила, кинески сан

\section{УВОД}

Читав век је прошао од 1. јула 1921. године, када је на тајном састанку у Шангају основана Комунистичка партија Кине. Након што је однела победу у грађанском рату, ова партија је 1949. године основала Народну Републику Кину. Током наредних неколико деценија руководство партије је успело да Културном револуцијом економски и друштвено разрушену и међународно изоловану државу трансформише у снажну и утицајну чланицу међународне заједнице. Да би пројектовала своју 
националну моћ и остварила своје циљеве - обезбеђивање довољно хране и енергената за становништво, присаједињење свих кинеских територија и опстанак Комунистичке партије Кине на власти - недуго након оснивања НР Кина је почела да спроводи политику давања инвестиција и помоћи иностранству (Arežina, 2018, str. 15).

Током педесетих и шездесетих година, средства која је Пекинг издвајао у ту сврху била су велика. Са отпочињањем политике „реформи и отварања према свету" 1978. године кинеско руководство почело је да смањује количину средстава коју је издвајало у ову сврху, пре свега због потребе да их преусмери у модернизацију земље (Selden, 1978). Тек на почетку 21. века, захваљујући свом изузетном економском расту и значајним финансијским ресурсима, НР Кина је поново почела да издваја значајнија средства за ову намену, на билатералном и мултилатералном нивоу.

Иако неки западни аутори имају сумње у мотиве кинеског инвестирања и давања помоћи иностранству, ауторка износи хипотезу овог истраживања да кинеско руководство развија модел давања инвестиција и помоћи иностранству са намером да покаже да НР Кина представља "одговорну велику силу" (Fuzeren de Daguo) која доприноси решавању важних глобалних проблема (Zoellick, 2005), док у исто време ради на остваривању најважнијег циља - достизања „кинеског сна” до 2049. године (Gong, 2013). ${ }^{1}$

У претходном периоду, истраживања о моделу инвестиција и помоћи иностранству углавном су била фокусирана на опште информације о инвестицијама и помоћи коју НР Кина даје иностранству. Ради се, пре свега, о подацима о структури, обиму и начину давања инвестиција и помоћи иностранству, као и институцијама које спроводе ову политику. ${ }^{2}$ У овом истраживању акценат је стављен на факторе који су утицали на кинеско руководство да развија модел давања инвестиција и помоћи иностранству заснован на „Пекиншком консензусу”. Да би доказала основну хипотезу, ауторка користи структурално-функционалну анализу како би ближе објаснила кинески модел давања инвестиција и помоћи иностранству и његов утицај на суседне државе и међународну заједницу.

1 Председник Си Ђинпинг је на Трећем пленуму 18. конгреса КПК у новембру 2012. године споменуо визију „кинеског сна”, која је накнадно објашњена као остварење великог броја унутрашњих реформи захваљујући којима ће НР Кина постати држава благостања.

2 Ради се о следећим истраживањима: Brautigam, D. (2009). The Dragon's Gift. New York: Oxford University Press; Wolf, C. J., Wang, X., Warner, E. (2013). China's Foreign Aid and Government Sponsored Investment Activities - Scale, Content, Destinations and Implications. Washington D.C.: RAND Corporation; Arežina, S. (2018). China in Europe. Belgrade: Institute of European Studies, и друга. 
Такође, она користи компаративну анализу како би извршила поређење овог модела са западним, који је заснован на „Вашингтонском консензусу", и поређење система давања кинеске мултилатералне помоћи иностранству са системом добијања помоћи преко система OECD који је својствен западним државама.

Чланак се састоји од пет делова. У уводном делу ауторка наводи контекст у коме ће се истраживање обавити, објашњава суштину проблема којим ће се бавити у чланку и поставља хипотезе. У другом делу ауторка објашњава историјат давања кинеских инвестиција и помоћи у иностранству. У трећем делу ауторка наводи факторе који су утицали на КПК да развија модел инвестиција и помоћи иностранству. У четвртом делу ауторка објашњава врсте и начин давања инвестиција и помоћи иностранству. У закључним разматрањима биће сумирано истраживање и закључци до којих се дошло, након чега ауторка даје пројекцију у ком правцу ће се развијати кинеска политика давања инвестиција и помоћи иностранству.

\section{ИСТОРИЈАТ ДАВАҢА КИНЕСКИХ ИНВЕСТИЦИЈА И ПОМОЋИ ИНОСТРАНСТВУ}

Иако и сама суочена са блокадом и ембаргом услед губитка наклоности и подршке Запада након оснивања 1949. године, НР Кина је почела да даје инвестиције и помоћ иностранству. Средства која је Пекинг издвајао у ту сврху педесетих и шездесетих година била су прилично велика и највећим делом су давана као подршка националној независности и развоју економија. Током седамдесетих година НР Кина је наставила са давањем инвестиција и помоћи иностранству превасходно како би парирала утицају Совјетског Савеза. Помоћ је већином давана социјалистичким земљама са којима је имала развијене партијске везе, марксистичко-лењинистичким покретима и неким суседним државама (Brautigam, 2009, p. 32).

Пекинг полако почиње да смањује количину средстава која су издвајана у ову сврху након преузимања столице у Уједињеним нацијама од Тајвана 1971. године. Разлог томе је што економски и друштвено разрушена након Културне револуције, политике „великог скока напред” и кампање „сто цветова” НР Кина није имала много тога да понуди ни сопственом становништву, а камоли свету. Зато је било неопходно да се окрене сопственом развоју, реформама и модернизацији земље, за шта јој је, пре свега, било неопходно мирно окружење. Међутим, велики 
„архитекта” реформи Денг Сијаопинг (Deng Xiaoping) остао је доследан својој тврдњи „да је помоћ иностранству била права ствар у прошлости, права ствар у садашњости и да ће бити права ствар и када се Кина развије". У наредних неколико деценија он ће поставити темеље променама у спољној политици и економији увођењем политике „реформи и отварања према свету”, „осмех дипломатије” и доктрине „24 карактера" (политика „бити стрпљив”; Kissinger, 2011, р. 539) дећих 35 година трансформисати НР Кину из Културном револуцијом економски и друштвено разрушене и међународно изоловане државе у снажну и утицајну чланицу међународне заједнице.

Захваљујући успешној стратегији економске модернизације, чији први корак је био „поздрављање уласка” (Yin Yinlai) значајних инвестиција из иностранства, НР Кина је 2001. године кренула са другом фазом економске модернизације - политиком „изласка на страна тржишта” ( „going out” политика, Zou Chuqu) вишка капитала са циљем да се продуби приступ страним тржиштима, природним ресурсима и напредним технологијама, доносећи додатни раст и стабилизацију. Ова политика је укључена у Десети петогодишњи план (2001-2005), чиме је формализована као једна од „четири модернизације” и примарни циљ економског развоја (Arežina, 2016, str. 14). То је значило да Пекинг поново отпочиње са издвајањем значајнијих средстава за давање инвестиција и помоћи иностранству.

У Једанаестом петогодишњем плану (2006-2010) влада је подстакла компаније да „и даље иду напоље” (Jinyibu Zouchuqu), док је у Дванаестом петогодишњем плану (2011-2015) фокус стављен на продубљивање дистрибутивне мреже и препознатљивост, као и на стицање напредних технологија и могућности истраживања и развоја (Sagers, 2012). Несигуран економски развој, наставак нестабилности на глобалним финансијским тржиштима и успоравање економског раста развијених држава подстакли су многе државе у развоју да усвоје политике прихватања спољних директних инвестиција као начин да постигну економски раст и направе бољи инвестициони амбијент, што је имало позитиван утицај на планове НР Кине отворивши јој пут да улаже у државе и регионе широм света $(16+1,2016)$. Стога је Тринаести петогодишњи план (2016-2020) у фокус ставио реформу кинеског друштва, коју је довео у везу са напредним технологијама. Дат је задатак да се економија НР Кине реструктурира од инвестиционог модела, који је заснован на јефтиној

Денг Сијаопинг је 1991. године формулисао ову политичку опоруку: „Мирно посматрајте, осигурајте нашу позицију; хватајте се у коштац са стварима мирне главе; кријте наше капацитете и чекајте повољну прилику; успешно се држите по страни и никада не претендујте на вођство". 
радној снази која производи јефтине производе за трећа тржишта, ка потрошачком моделу, заснованим на производњи напредних технологија, које ће да купује кинеско становништво (Zapoljskis, 2016). У складу са тим, кинеско руководство је 2015. године објавило стратегију „произведено у Кини" (Zhongguo Zhizao 2025; Lempton, 2015, p. 38). ${ }^{4}$

Нови Четрнаести петогодишњи план (2021-2025) узима у обзир нове међународне околности и појаву COVID-19 пандемије, у складу са којима ставља фокус на „двоструку циркулацију”, која би требало да омогући коришћење свих предности глобализације уз истовремено коришћење сопствених капацитета. То значи да ће један део финансијских средстава, који је у претходном периоду одлазио у иностранство путем инвестиција и помоћи, бити донекле смањен и усмерен на јачање кинеске привреде. Крајњи циљ је да кинеско друштво постане самодовољно и независно од европског, америчког или афричког тржишта, и да се формира „друштво средње класе” које ће имати довољно висок животни стандард да може да купује високотехнолошке производе које производе кинеске компаније (Arežina, 2018, str. 17).

У складу са овим плановима, прилагођавале су се иницијативе и пројекти које је кинеско руководство покретало у међувремену. Највећа и глобално најпознатија кинеска иницијатива „Један појас, један пут” (Yidai Yilu) промовисана је 2013. године са циљем да повеже два економски развијена краја Евроазије (Западну Европу и источни део НР Кине), али и остале континенте Африку, Јужну Америку и Аустралију. Процењује се да овај пројекат обухвата око 4,4, милијарде људи (64\% светске популације) и државе које праве око 40\% светског БДП. Према најавама кинеског председника Сиа Ђинпинга (Xi Jinping) из 2017. године, очекује се да вредност овог пројекта достигне преко хиљаду милијарди долара, при чему би креирао запослење за неколико милиона људи и генерисао више од 100 милијарди долара прихода од пореза. Зато га је назвао „пројектом века", који би требало да донесе благодат свим државама које се налазе дуж „новог пута свиле” (Kynge, Wheatley, 2020).

Стратегија има за циљ јачање кинеске индустрије високе технологије и пласирање ових производа широм света. 


\section{ФАКТОРИ КОЈИ СУ УТИЦАЛИ НА КОМУНИСТИЧКУ ПАРТИЈУ КИНЕ ДА РАЗВИЈА МОДЕЛ ИНВЕСТИЦИЈА И ПОМОЋИ ИНОСТРАНСТВУ}

Током деценија, многобројни фактори су утицали на кинеско руководство да настави са политиком инвестиција и помоћи иностранству. Неки од фактора били су изразито доминантни само у одређеном периоду, да би касније њихов утицај слабио, а јачао утицај других фактора, док су неки од њих све време били константни. Стога ће у наставку бити наведени најважнији од њих.

Први фактор је жеља кинеског руководства да НР Кина буде представљена као партнер на кога државе, посеб́о оне са којима има добре односе, могу да се ослоне. Овај фактор је био актуелан још током педесетих и шездесетих година 20. века, када је Пекинг пружао подршку свим државама које су желеле да остваре независност и развију своје економије, како би кроз сарадњу са њима разбио економску блокаду наметнуту са Запада. Након завршетка Хладног рата, као пандан западном „Вашингтонском консензусу”, НР Кина је развила сопствени „тржишно-лењинистички" модел пружања економске помоћи, назван „Пекиншки консензус" (Cooper Ramo, 2004, p. 39).

Други значајан фактор је задовољење потреба унутрашњег тржишта за животно важним ресурсима и прекоморским тржиштима за дистрибуцију и продају домаћих производа. Да би могла да реализује овај циљ спољне политике НР Кина је две деценије радила на развоју инвестиционог модела развоја, стављањем у фокус "going out" политике и указујући на потреб́ "win-win" сарадње са државама широм света (Zha, Breslin, 2010, p. 67).

Још један значајан фактор је потреба за интернационализацијом кинеских компанија и националне валуте јуана. У том циљу, кинеско руководство је омогућило излазак на страна тржишта кинеским компанијама у државном власништву и приватним компанијама средње величине, како би улагале у различите пројекте од интереса за национални опоравак и повећавале своју видљивост преузимајући познате брендове и напредне технологије потребне за развој домаће економије (Hong, Hou, 2017, p. 55).

Четврти важан фактор је потреба кинеске владе да се, услед страха од губитка куповне моћи долара, ослободи девизних резерви, посебно оних које има у доларима, и пребаци их у злато и друге валуте (тзв. дедоларизација). Разлог за то је незадовољство доларом као резервном валутом, које нараста у свету због непрекидне енормне емисије нових 
количина те валуте, пре свега услед повећања потрошње америчке владе, што изазива страх свих који чувају доларе од губитка његове куповне моћи (Arežina, 2018, str. 94).

Пети фактор је јачање кинеског положаја у међународним организацијама. Како би заузела место у Уједињеним нацијама (уместо Тајвана), њеним специјализованим агенцијама и другим међународним организацијама, НР Кина је још педесетих и шездесетих година 20. века успоставила сопствени систем давања мултилатералне помоћи иностранству без укључивања у оквир помоћи OECD-a, који је својствен западним државама (Miljanić, 1996, str. 30). Развијено је релативно блиско партнерство са глобалним и регионалним мултилатералним развојним организацијама, као што су Програм Уједињених нација за развој, Светска банка, Азијска развојна банка, али и развијене сопствене мултилатералне развојне институције, попут Азијске инфраструктурне и инвестиционе банке. У последњих неколико година, форме и облици мултилатералне помоћи коју НР Кина даје постали су знатно разноврснији и диверзификованији, а количина новца која се опредељује у ту сврху знатно је повећана (Hong, Hou, 2017, p. 11).

Шести важан фактор је потреба НР Кине да повећа своју „меку моћ”. Наиме, давање инвестиција и помоћи иностранству помаже интернационализацији кинеске културе, служећи као један вид културне дипломатије, поред 1.000 института Конфуције, који постоје широм света, и кинеских културних центара који промовишу „кинески сан” на међународном нивоу (по угледу на Alliance Française, British Council i GoetheInstitut; Arežina, 2018, str. 98).

У исто време, НР Кина је развојем модела давања инвестиција и помоћи иностранству желела позитивно да утиче на западне државе и међународне организације да повећају инвестиције и помоћ иностранству за развој инфраструктуре и смање политичка условљавања (Milanović, 2021). Тако су САД након 2017. године отпочеле „тихе разговоре" са америчким партнерима како створити алтернативне механизме финансирања у односу на иницијативу „Један појас, један пут”, које би понудили државама којима је потребан прилив капитала, што је политика која је настављена и након доласка председника Џо Бајдена (Joe Biden) на власт у јануару 2021. године (Smith, 2018; Aljazeera, 2021; Miki, 2021).

Међутим, вероватно најважнији фактор је очување територијалног интегритета и присаједињење свих кинеских територија које је Кина изгубила током „века понижења”. Устав НР Кине сугерише да је „свети циљ" поновног уједињења земље задатак сваког Кинеза и неизбежан историјски ток (Medeiros, 2009). Јачајући партнерства са државама широм 
света НР Кина ради на реализацији свог циља, док истовремено доноси благодат другим државама.

\section{КИНЕСКЕ ИНВЕСТИЦИЈЕ И ПОМОЋ ИНОСТРАНСТВУ}

Количина кинеских директних инвестиција у иностранству постала је много већа откако је НР Кина достигла економску стабилност почетком 21. века. Наиме, за разлику од периода 1982-1989. године, када су стране директне инвестиције иностранству износиле мање од 500 милиона долара, у периоду 1990-1999. године овај износ је порастао на нешто изнад две милијарде долара, док су 2000. кинеске директне инвестиције у иностранству износиле мање од 2,3 милијарде долара. Са почетком примене "going out" политике 2001. године, кинеске директне инвестиције су порасле. Тако су кинеске инвестиције у иностранству 2005. године достигле 72,4 милијарде долара и наставиле да се повећавају сваке године, да би 2015. износиле 135,6 милијарди долара (Blanchard, 2017). Процењује се да је од почетка политике „реформи и отварања према свету” до 2020. године НР Кина, путем припајања, преузимања или оснивања joint venture, пласирала преко 1.500 милијарди долара директних инвестиција у свет (World Economic Forum, 2017; EY, 2021).

Како није постојало планско и рационално улагање кинеског капитала у иностранству, у августу 2017. године руководство НР Кине је донело одређене рестриктивне прописе да би појачали контролу над финансијским средствима која излазе из земље и тиме наставили са развојем кинеске економије и смањили улагање у секторе који нису од централног интереса за владу, нити у складу са државним дугорочним циљевима и директивама. Резултат тога је био да су до краја 2017. години кинеске директне инвестиције у иностранству опале за 46\% (Hsu, 2017).

По питању давања помоћи иностранству Пекинг је развио сопствени модел - помоћ са кинеским карактеристикама - заснован на „Пекиншком консензусу”. Овај модел помоћи не користи политику „штапа и шаргарепе", за разлику од западног модела који је укорењен у идејама Маргарет Тачер (Margaret Thatcher) и Роналда Регана (Ronald Reagan), односно на „Вашингтонском консензусу” који се заснива на сету мера које прималац помоћи треба да испуни, познатим као „шок терапија", попут консолидације државног буџета, фискалне дисциплине и др. У складу са кинеским прагматизмом и идеализмом, овај модел утемељење налази у пет начела мирољубиве коегзистенције која су 
установљена 1954. године, Осам принципа кинеске помоћи иностранству, које је Џоу Енлај (Zhou Enlai) објавио на турнеји по Африци 1964. године, Четири принципа економске и техничке сарадње, које је Џао Цијанг (Zhao Ziyang) објавио током посете Африци почетком 1983. и "going out" политици (Bernasconi-Osterwalder, et al., 2013, pp. 1-2). У исто време, кинески модел помоћи заснива се на три принципа: иновације и прилагодљивост локалним условима (ангажовање напредне технологије радије него ширење технологија ниског нивоа), одрживост и стабилност (улагање у инфраструктуру и природне ресурсе) и очување независности (немешање у унутрашњу политику држава корисница као једно од пет начела мирољубиве коегзистенције; Jurišić, 1999, str. 38).

Кинеска помоћ иностранству може се поделити на билатералну и мултилатералну помоћ. Постоји најмање девет врста билатералне помоћи које НР Кина даје иностранству: медицински тимови, обука и стипендије, хуманитарна помоћ, млади волонтери, отпис дуга, буџетска подршка, пројекти „кључ у руке” (инфраструктура, фабрике, итд.), помоћ у натури и техничка помоћ. Неке од ових врста помоћи у примени су дужи период, док су друге потпуно нове (Bernasconi-Osterwalder, et al., 2013, p. 105). Међутим, најчешће се мисли на три начина давања финансијске помоћи: грантови (бесповратна помоћ), бескаматни зајмови и повлашћени зајмови.

Када је у питању мултилатерална помоћ, НР Кина је још педесетих година 20. века успоставила сопствени систем давања помоћи иностранству, мимо оквира помоћи OECD-а који је својствен западним државама. Разлог за то је што се НР Кина и даље декларише као држава у развоју, те помоћ која стиже из Пекинга има мањи проценат гранта у односу на помоћ која се добија преко система OECD, због чега западне институције кинеску помоћ иностранству често квалификују као Званично развојно финансирање (ODF), а не као Званичну развојну помоћ (ODA; Hong, Hou, 2017, p. 51).

НР Кина је успоставила релативно блиско партнерство са глобалним и регионалним мултилатералним развојним организацијама, као што су Програм Уједињених нација за развој, Светска банка, Азијска развојна банка и др. (Hong, Hou, 2017, p. 51). У почетку се кинеска мултилатерална помоћ иностранству састојала само од две форме помоћи: донација и плаћања чланства у међународним организацијама. Са развојем система давања мултилатералне помоћи иностранству долази до њихове диверзификације, те се може рећи да данас постоје донације и чланарине у међународним организацијама, финансирање капитала и зајмови и пројектна сарадња са међународним организацијама (Jurišić, 1999, p. 38). 
Кинески извори тврде да је НР Кина у периоду од 1950. до 2016. године обезбедила више од 400 милијарди јуана помоћи иностранству, да је започето више од 5.000 пројеката, од чега је завршено скоро 3.000, и да је одржано преко 11.000 тренинг програма у НР Кини за више од 260.000 чланова особља из других држава у развоју (World Economic Forum, 2017). Према подацима Државног савета НР Кине, само у периоду 2013-2018. године кинеске финансијске институције алоцирале су 270,2 милијарде јуана помоћи иностранству, које су подељене у три категорије - грантови, бескаматни зајмови и повлашћени зајмови (Тhe State Council of the PR China, 2021). Значајан део ове врсте помоћи одлази на 2.600 пројеката вредних 3.700 милијарди долара који су покренути у оквиру иницијативе „Један појас, један пут” (Aljazeera, 2021).

Услед појаве COVID-19 пандемије дошло је до смањења кинеског економског раста са 6\% у 2019. на 2,3\% у 2020. години (Cheng, 2021). То је за последицу имало увођење политике „двоструке циркулације", која је довела до значајног пада кинеске помоћи иностранству, са 75 милијарди долара, колико је износила на врхунцу у 2016, на четири милијарде долара у 2020. години (Kynge, Wheatley, 2020). Међутим, свесна своје улоге „одговорне велике силе” НР Кина је током 2020. године почела да развија нову компоненту иницијативе „Један појас, један пут" - здравствени пут свиле. У оквиру ње, Пекинг је успоставио значајне механизме сарадње између кинеских здравствених институција и здравствених институција у разним регионима, послао државама значајну помоћ у реаговању на COVID-19 пандемију (тестове, заштитну опрему и вакцине) и подршку за економски и социјални опоравак државама у развоју (отпис и рефинансирање дугова) (Xinhua, 2021; Qiu, Woo, 2020).

\section{ЗАКљУЧАК}

Полазна основа овог истраживања је дугорочна политика давања инвестиција и помоћи иностранству, коју је кинеско руководство почело да спроводи након оснивања Народне Република Кине 1949. године. Иако се количина средстава која је опредељивана у ову сврху мењала у складу са околностима у којима је кинеско руководство водило државу, никада се није одустало од овакве врсте сарадње са суседним државама и међународном заједницом, чак ни у периоду када је Народна Република Кина била једнако сиромашна као и државе које су од ње примале помоћ, нити када јој је приоритет постао усмеравање свих финансијских капацитета у економски развој. 
Како је за доказивање хипотезе најважнији ангажман кинеског руководства по питању решавања важних глобалних проблема, док у исто време раде на остваривању најважнијег циља - достизања „кинеског сна" до 2049. године, ауторка је у истраживању акценат ставила на факторе који су утицали на кинеско руководство да развије посебан модел давања инвестиција и помоћи иностранству који је заснован на „Пекиншком консензусу". Током истраживања, дошла је до закључка да су неки од фактора били изразито доминантни само у одређеном периоду, да би касније њихов утицај слабио, а јачао утицај других фактора, док су неки од њих све време били константни. Сви фактори деловали су позитивно на кинеско руководство да пронађе win-win решења и настави са давањем инвестиција и помоћи иностранству, упркос променама кинеских приоритета током спровођења политике „реформи и отварања према свету" и COVID-19 пандемије.

У исто време, ауторка је дошла до закључка да се модел давања инвестиција и помоћи иностранству значајно разликује од западног модела који основу има у „Вашингтонском консензусу”, да се систем давања кинеске мултилатералне помоћи иностранству разликује од помоћи која се добија преко система OECD који је својствен западним државама, да развијајући такмичење са Западом овај модел значајно доприноси повећању инвестиција и помоћи иностранству (посебно државама у развоју), као и да, иако су се мењали начин давања и количина средстава која је опредељивана од стране кинеског руководства у сврху инвестирања и давања помоћи иностранству, овај модел је ипак деценијама остао централна тачка кинеске спољне политике.

У вези са тим, ауторка је указала да је током деценија развоја кинеско руководство настојало да контролише и усмерава развој овог модела усклађујући га са плановима за рационално улагање кинеског капитала у иностранству. Сходно томе, у августу 2017. године влада је донела одређене рестриктивне прописе, у складу са којима је смањена количина средстава која је Народна Република Кина пласирала у иностранство у наредним годинама (само у 2017. години смањење је износило готово 46\%).

Нова промена у количини средстава која излазе из НР Кине уследила је након појаве COVID-19 пандемије и значајног смањења кинеског економског раста. Упркос потреби да део средстава преусмери из иностранства у развој домаћег тржишта и дугорочне планове за остварење „кинеског сна”, ауторка указује да кинеско руководство није одустало од намере да Народна Република Кина настави да буде присутна у иностранству. У вези са тим, покренули су нову компоненту иницијативе „Један појас, један пут" - здравствени пут свиле - захваљујући којој је 
међународној заједници пружена значајна помоћ током COVID-19 пандемије.

На крају, узимајући у обзир резултате истраживања, ауторка закључује да је кинески модел давања инвестиција и помоћи иностранству умногоме допринео да суседне државе и међународна заједница осете благодат њеног економског развоја. У исто време, НР Кина је постала прва држава у свету по трговинском обиму, друга економска сила, највећи поседник девизних резерви, највећи давалац људства за мировне мисије Уједињених нација, а сиромаштво је искорењено у потпуности. Након појаве COVID-19 пандемије 2020. године, тринаеста генерација кинеског руководства поступила је веома одговорно позивајући међународну заједницу на сарадњу, поштену дистрибуцију COVID-19 вакцина, одрицање права на интелектуално власништво над вакцинама и пренос технологије прављења COVID-19 вакцина државама у развоју у циљу заједничке производње (Xinhua, 2021). Све наведено говори у прилог томе да Народна Република Кина представља „одговорну велику силу", која доприноси решавању важних глобалних проблема, док у исто време ради на остваривању најважнијег циља - достизања „кинеског сна" до 2049. године.

У наредном периоду, у складу са новом Белом књигом о међународној развојној сарадњи, која је објављена 10. јануара 2021. године, ауторка очекује да ће Пекинг наставити да својим економским растом помаже глобални развој, уз неизбежно прилагођавање новим околностима до којих ће доћи у периоду током и након завршетка COVID-19 пандемије.

\section{ЛИТЕРАТУРА}

1. Aljazeera (2021, March 26). Biden suggests creating initative to rival China's Belt and Road; https://www.aljazeera.com/economy/2021/3/26/biden-suggests-creating-initiative-to-rival-chinas-belt-and-road (10.10.2021).

2. Arežina, S. (2018). China in Europe. Belgrade: Institute of European Studies.

3. Arežina, S. (2014). Chinese 'going out' policy and its impact on relations with Serbia. Review of International Affairs, LXV (1153-1154): 5-23.

4. Cheng, Y. N. (2014). Virtual trading assessment techniques based on China's foreign exchanges reserves data. In: H.-C. Liu, W.-P. Sung, W. Yao (eds.), Computer, Intelligent Computing and Education Technology. London: Taylor \& Francis Group; https://doi.org/10.1201/9781315760810 (10.10.2021). 
5. Bernasconi-Osterwalder, N. et al. (eds.) (2013). Chinese Outward Investment: An emerging policy framework. IISD; http://www.iisd.org/pdf/2012/chinese_ outward_investment.pdf (11.10.2021).

6. Blanchard, J.-M. F. (2017, April 14). The Security Implications of China's Overseas Investment Boom. The Diplomat; https://www.ey.com/en_cn/china-overseas-investment-network/overview-of-china-outbound-investment-of-q1-2021 (11.10.2021).

7. Brautigam, D. (2009). The Dragon's Gift. New York: Oxford University Press.

8. Cheng, E. (2021, January 17). China says its economy grew $2.3 \%$ in 2020 , but consumer spending fell. CNBC; https://www.cnbc.com/2021/01/18/chinaeconomy-release-of-fourth-quarter-full-year-2020-gdp.html (12.10.2021).

9. Chow, L. (2021, February 8). Overview of China outbound investment of 2020. $E Y$; https://www.ey.com/en_cn/china-overseas-investment-network/overview-of-china-outbound-investment-of-2020 (13.10.2021).

10. Cooper Ramo, J. (2004). The Beijing Consensus. London: The Foreign Policy Centre.

11. Gong, W. (2013, November 23). Chinese Experience of Development. Lecture, Seminar „China's issues”. Beijing: Chinese Academy of Governance.

12. Hong, Z., Hou, X. (2017). China's Foreign Aid, Singapore: Springer.

13. Hsu, S. (2017, August 28). China's New Capital Controls Expected to Slow Real Estate, but improve Country's Economic Health. Forbes; https://www. forbes.com/sites/sarahsu/2017/08/28/chinas-new-capital-controls-expectedto-slow-real-estate-but-improve-countrys-economic-health/\#6e2de76f66fd (09.10.2021).

14. Jurišić, K. (1999). Half a century of the PR China. Politička misao, 36 (3): 34-44.

15. Kissinger, H. (2011). On China. New York: Penguin Press.

16. Kynge, J., Wheatley J. (2020, December 11). China pulls back from the world: Rethinking Xi's 'project of century'. Financial Times; https://www.ft.com/content/d9bd8059-d05c-4e6f-968b-1672241ec1f6 (07.10.2021).

17. Lempton, D. M. (2015). Follow the leader. Beograd: CIRSD.

18. Medeiros, E. S. (2009). China as International Actor: Activism, Opportunism and Diversification. Santa Monica: RAND Corporation.

19. Milanović, B. (2021, May 21). Competition Can Be Good for the Developing World. Foreign Affairs; https://www.foreignaffairs.com/articles/china/2021-05-21/competition-can-be-good-developing-world?utm_campaign=fb_daily_soc\&utm_source=facebook_posts\&utm_medium=social (10.10.2021).

20. Miljanić, D. (1996). The oscillations in the US-China relations. Međunarodna politika, 47 (1042): 29-32. 
21. Miki, R. (2021, April 6). US and Japan plan 'Belt and Road' alternative for IndoPacific. NikkeiAsia; https://asia.nikkei.com/Politics/International-relations/ Indo-Pacific/US-and-Japan-plan-Belt-and-Road-alternative-for-Indo-Pacific (18.10.2021).

22. Rosen, D. H., Hanemann T. (2009). China's Changing Outbound Direct Investment Profile: Drivers and Policy Implications. Policy Brief PB09-14. Washington: Peterson Institute for International Economics.

23. Sagers, C. (2012, May 10). China's 'Going Out' Strategy. Diplomatic Courier; http://www.diplomaticourier.com/news/regions/brics/952?showall=1, 20. 6 . 2017 (12.10.2021).

24. Selden, M. (ed.) (1979). The People's Republic of China: A Documentary History of Revolutionary Change. New York\&London: Monthly Review Press.

25. Smith, J. (2018). China's Belt and Road Initiative: Strategic Implications and International Opposition. The Herirage Foundation; https://www.heritage.org/asia/report/chinas-belt-and-road-initiative-strategic-implications-and-international-opposition (15.10.2021).

26. The State Council of the PR China. (2021, January 10). Full text: China's International Development Cooperation in the New Era; http://english.www.gov. cn/archive/whitepaper/202101/10/content_WS5ffa6bbbc6d0f72576943922.html (17.10.2021).

27. Trading Economics. (2017, August 31). China Foreign Exchange Reserves 1980-2017; https://tradingeconomics.com/china/foreign-exchange-reserves (13.10.2021)

28. Zapoljskis, A. (2016, March 17). China has announced that it will triple the standard of living for 70 million people a year. Fakti; http://fakti.org/globotpor/kina/kina-objavila-da-ce-utrostrucavati-zivotni-standard-za-po-70-miliona-ljudi-godisnje (14.10.2021).

29. Zha D., Breslin S. (2010). Oiling the weels of foreign policy? Energy security and China's international relations. In: Shaun Breslin (ed.) Handbook of China's International Relations (64-75). London: Routledge International Handbook.

30. Zoellick, R. B. (2005, September 21). Whither China: From Membership to Responsibility? Remarks prepared for delivery to National Committee on USChina Relations. New York City: US Department of State.

31. World Economic Forum (2017, January 17). President Xi's speech to Davos in full; https://www.weforum.org/press/2021/01/president-xi-jinping-s-speech-at-davos-agenda-is-historic-opportunity-for-collaboration/ (09.10.2021).

32. Qiu, S., Woo, R. (2020, November 20). China says has given $\$ 2.1$ billion of debt relief to poor countries. Reuters; https://www.reuters.com/article/us-chinadebt-g20-idUSKBN28009A (12.10.2021). 
33. Xinhua. (2021, May 21). Remarks by Chinese President Xi Jinping at the Global Health Summit; http://www.xinhuanet.com/english/2021-05/21/c_139961512.htm (11.10.2021).

34. 16+1 (2016, January 11). Analysis of China's Investment in CEECs under the New Situation; http://16plus1-thinktank.com/1/20160111/1091.html (11.10.2021).

Sanja Zoran Arežina

\title{
THE ROLE OF THE COMMUNIST PARTY OF CHINA IN THE DEVELOPMENT OF THE CHINA'S INVESTMENT AND FOREING AID MODEL
}

\begin{abstract}
The People's Republic of China started implementing its foreign investment and foreign aid policies in 1950s. Although their motivation has changed in the meantime, Chinese leadership has never given up its decision that foreign investment and aid should constitute the central part of the Chinese foreign policy. To prove the premise that the fundamental reason for the development of this Chinese model of foreign investment and aid is the intention of the Chinese leadership to prove that the People's Republic of China is "a responsible great power" which contributes to the resolution of important global problems, while at the same time trying to achieve its paramount goal - "Chinese dream" until 2049, the author uses structural-functional and comparative analyses.
\end{abstract}

Keywords:

China, investment, aid, responsible great powers, Chinese dream. 